Technical Note

\title{
Joint Terrestrial and Aerial Measurements to Study Ground Deformation: Application to the Sciara Del Fuoco at the Stromboli Volcano (Sicily)
}

\author{
Alessandro Bonforte ${ }^{1, *}$, Pablo J. González ${ }^{2}$ and José Fernández ${ }^{3}$ \\ 1 Istituto Nazionale di Geofisica e Vulcanologia, Sezione di Catania-Osservatorio Etneo, Catania 95125, Italy \\ 2 COMET, Institute of Geophysics and Tectonics, School of Earth and Environment, University of Leeds, \\ Leeds LS2 9JT, UK; pabloj.glez@gmail.com \\ 3 Institute of Geosciences, CSIC, UCM, School of Mathematics, Ciudad Universitaria, 28040-Madrid, Spain; \\ jft@mat.ucm.es \\ * Correspondence: alessandro.bonforte@ingv.it; Tel.: +39-095-7165800
}

Academic Editors: Ruiliang Pu and Prasad S. Thenkabail

Received: 14 April 2016; Accepted: 25 May 2016; Published: 31 May 2016

\begin{abstract}
The 2002-2003 Stromboli eruption triggered the failure of part of the Sciara del Fuoco slope, which generated a tsunami that struck the island and the northern coastline of Sicily. The Sciara del Fuoco is a very steep slope where all lava flows from the craters' emplacement; most lateral eruptions usually take place from fissures propagating in this sector of the volcano. The eruption went on to produce a lava field that filled the area affected by the landslide. This in turn led to further instability, renewing the threat of another slope failure and a potentially related tsunami. This work describes a new joint approach, combining surveying data and aerial image correlometry methods, to study the motion of this unstable slope. The combination has the advantage of very precise surveying measurements, which can be considered the ground truth to constrain the very-high-resolution aerial photogrammetric data, thereby obtaining highly detailed and accurate ground deformation maps. The joint use of the two methods can be very useful to obtain a more complete image of the deformation field for monitoring dangerous and/or rather inaccessible places. The proposed combined methodology improves our ability to study and assess hazardous processes associated with significant ground deformation.
\end{abstract}

Keywords: surveying; data integration; aerial photogrammetry; monitoring; flank instability; sector collapse; landslide; tsunami; volcanoes

\section{Introduction}

Active volcanoes represent a rapid temporally changing morphological terrain. Local topography is modified due to new material deposition, rapid erosion, compaction, and/or mass-wasting processes. Some of those morphological processes are associated with hazardous events, such as tsunami-generating landslides. Therefore, keeping up-to-date topographic maps and tracking its temporal changes is important to evaluate natural hazards. Rapid updates of topographic maps, digital elevation models (DEM), and terrain displacement maps have been made in the past to characterize the morphological changes of very active volcanoes [1,2]. The most popular technique is photogrammetry, as it has been widely used to determine topography and its temporal changes with a precision on a scale of meters [3]. Radar techniques have been also used to determine topography with a comparable precision. In addition, the applications of differential radar techniques are able to track changes in a narrow range, from millimeters to centimeters [4]. However, sudden topographic changes on a scale of tens of centimeters are difficult to capture, either with photogrammetric or 
with radar technology, when they produce a decorrelation between the two images. Optical imagery cross-correlation or optical correlometry can be used to measure topographic changes, particularly horizontal ground displacements with sub-pixel precision [5-9]. Optical correlometry can therefore provide the capability of partially filling the observational gap. Here, we propose using optical correlometry of high-resolution aerial orthoimagery to determine surface ground displacements on a scale from tens of centimeters to several meters. Then, using a multisensor approach, namely a combination of techniques, would allow for the extension of a range of track changes in topography.

Stromboli is the northernmost island of the Aeolian Archipelago volcanic arc (Southern Tyrrhenian Sea, Italy). It is a composite volcano, rising about $2500 \mathrm{~m}$ above the sea floor, with its summit at about $1 \mathrm{~km}$ above sea level. The volcanoes of this arc developed between 1.3 Ma and the present [10]. The central part of the archipelago is still active and represents a transition zone between two geodynamically different domains with a continental collision and inactive volcanoes in the west and a subduction process and active volcanism in the east [11,12]. Stromboli has a complex construction process characterized by repeated sector collapses that have occasionally affected large portions of the edifice [13]. The overall conical shape of the volcano is broken by a large depression in the northwestern flank of the edifice: the Sciara del Fuoco (SdF). The SdF continues below the sea, down to 700-750 m b.s.1.; this scar was produced by a huge sector collapse, on a scale of 1 cubic $\mathrm{km}$, that very likely originated during the Holocene [14]. The sliding of the SdF is constant, also producing continuous rockfalls $[15,16]$.

On 30 December 2002, two landslides occurred on the northern part of the SdF and generated a tsunami. The total volume of the landslides was estimated at about 17 million cubic meters from photogrammetric and bathymetric data [17]. The landslides took place where the new lava flow had emplaced a few days before. After the landslide, several flows overflowed on the same sector, forming a new lava terrace; this morphological element was a major concern after the end of the eruption, as it made the NE sector of the Sciara del Fuoco unstable once again.

The aim of this work is to test, compare, and integrate two independent datasets of ground deformation measurements, coming from a robotized surveying system and from orthoimages. One objective is to assess the suitability of this joint approach for monitoring the motion of this unstable slope of the volcano. Terrestrial techniques are more precise, but data are limited to sparse locations. Conversely, remote sensing techniques (though not so precise) allow covering wider areas with a higher spatial resolution. They help define the shape and dimension of the moving body and can provide important parameters, together with the kinematics of the motion, for hazard evaluations. For a correct estimation of the applicability, a comparison and joint interpretation of results is needed with both techniques, allowing for the validation of remote sensing. Once the technique is validated, it can also be used as a unique observation technique to monitor hazardous and remote active areas.

\section{Materials and Methods}

\subsection{Terrestrial Ground Deformation Monitoring System}

During the 2002-2003 eruption, a terrestrial monitoring network was installed to routinely measure the motion of benchmarks inside the SdF $[15,16,18,19]$. This network progressively evolved to an automatic system, named THEODOROS (THEOdolite and Distancemeter Robot Observatory of Stromboli), based on a remotely controlled robotized Total Station. It was aimed at measuring the pattern of the deformation from upper to lower altitudes (see Supplementary Material).

\subsection{Aerial Image Correlometry}

Stromboli volcano has been routinely imaged using aerial photogrammetric surveys during the last several eruptions for the estimation of volume changes, the detection of motion, and the rapid response to volcanic crises [3,20]. From the available dataset (Table 1), 3 maps have been obtained comparing images from three different dates (September 2003, August 2004, and May 2005) to track 
the lava terrace behavior since its emplacement, because the first image (May 2003) showed artifacts, making it unusable [21]. The resulting orthoimages were generated using standard photogrammetric methods, but with high performance, due to the in-situ collection of data at 20 GPS ground control points and the inertial system and GPS technology to control the camera position and orientation with high accuracy [20]. Quality and geometric control of the orthoimagery is presented in detail in [3,20], which follows the methodology of [22] (see Supplementary Material for a more detailed description of the procedures).

Table 1. Summary of the orthoimagery dataset used in this work. RGB indicates true color images, while grayscale are panchromatic. GSD stands for ground sample distance presented in meters $(\mathrm{m})$.

\begin{tabular}{ccc}
\hline Date & Image Type & GSD (m) \\
\hline 26 May 2003 & RGB & 0.5 \\
4 September 2003 & Grayscale & 0.2 \\
4 August 2004 & RGB & 0.5 \\
20 May 2005 & Grayscale & 0.2 \\
\hline
\end{tabular}

Three different image pairs were cross-correlated to analyze the deformation processes affecting the Sciara del Fuoco between mid- to late 2003 and mid-2005 (September 2003-August 2004, September 2003-May 2005, and August 2004-May 2005). The correlation was computed every 8 pixels using a correlation window size of 32 pixels.

\section{Results}

Independent ground deformation measurements using the THEODOROS system and 3D point coordinates measured manually on the photogrammetric stereo models are available for the studied period (Figure 1). Horizontal displacements obtained using those systems are shown in Figure 1b,c. Both datasets show a similar pattern, highlighting the maximum motion during the 2003-2004 period with maximum displacements at an altitude of about $550 \mathrm{~m}$ a.s.l.. Some reflectors of the THEODOROS system are affected by very little displacements, enabling confinement of the deforming area.

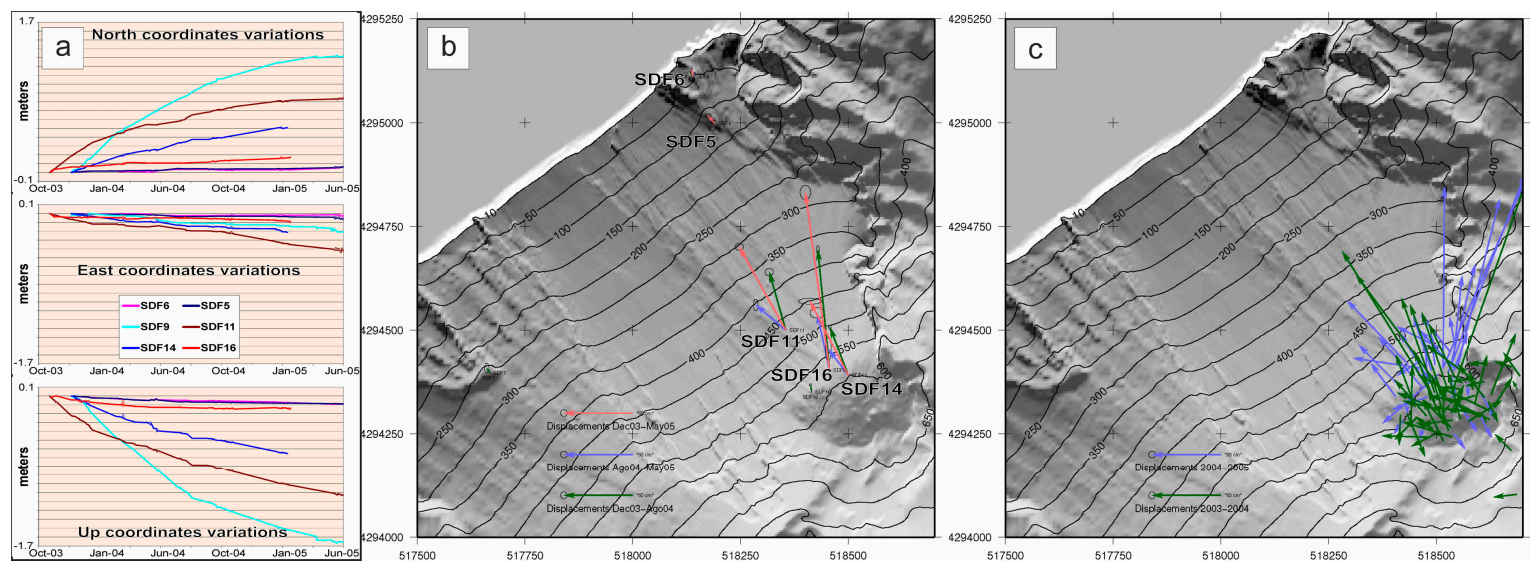

Figure 1. (a) Displacement time series recorded by THEODOROS system on the benchmarks; (b) Horizontal ground deformation registered by the THEODOROS monitoring system; red arrows for the entire 2003-2005 period, green arrows for the 2003-2004, and blue arrows for the 2004-2005 one; (c) Horizontal ground deformation measured by 3D single point measurement.

The results of the image correlation are shown as the 2D modulus of the horizontal deformation, computed as $\sqrt{u_{n s}^{2}+u_{e w}^{2}}$ in Figure 2, which clearly indicates that the deformation is restricted to the lava terrace formed at the end of the 2002-2003 Stromboli effusive eruption; decorrelated areas have been masked out in the figure. 

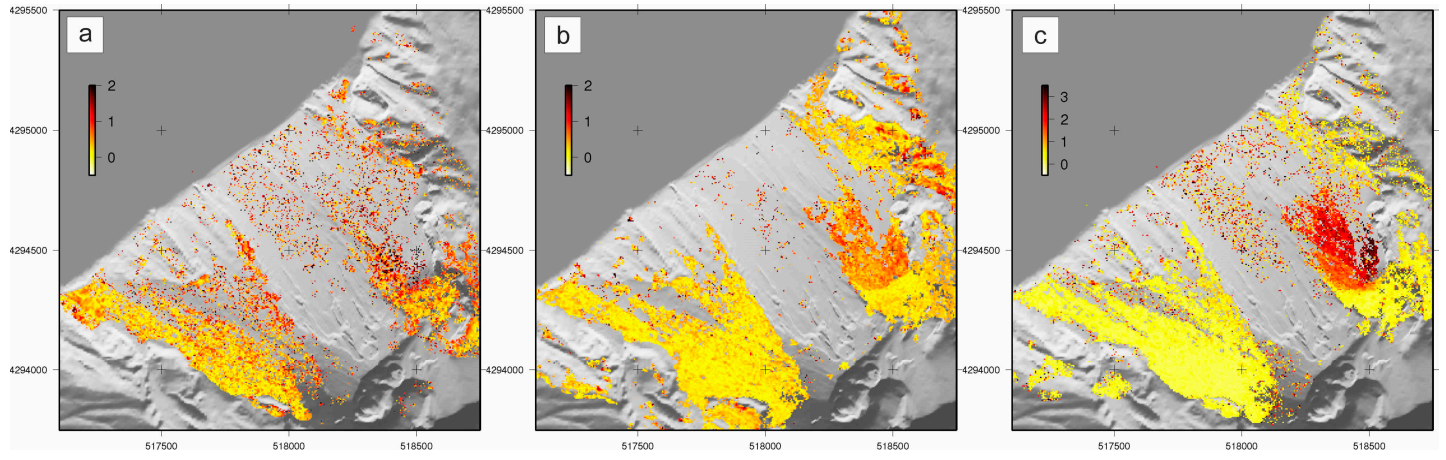

Figure 2. Magnitude (2D modulus) of the horizontal deformation (in meters). (a) September 2003-August 2004; (b) August 2004-May 2005; and (c) September 2003-May 2005. A-A' and B-B' dashed lines indicate the track of the profiles shown in Figure 3.
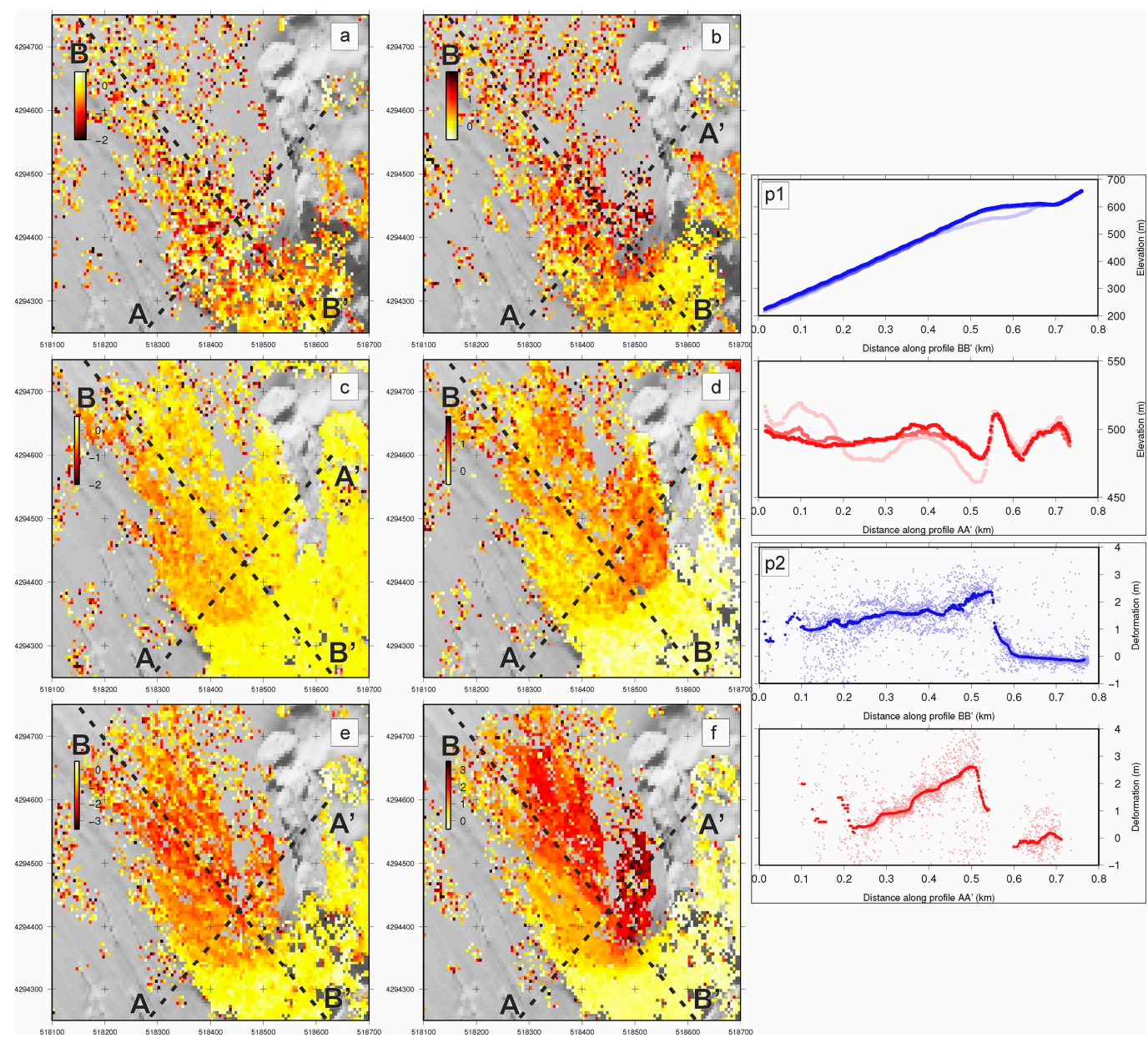

Figure 3. Maps showing the magnitude of the horizontal deformation (meters). From top to bottom, panels (a,b) show horizontal displacements from September 2003 to August 2004; (c,d) from August 2004 to May 2005 and (e,f) from September 2003 to May 2005. Left column (panels a,c,e) shows EW component. central column (panels b,d,f) shows NS component. (p1) Digital elevation models (DEM) profiles: blue profile indicates the $\mathrm{AA}^{\prime}$, corresponding to the maximum slope direction; $\mathrm{BB}^{\prime}$ is shown in red. Color intensities indicate different dates, darker more recent; see Figure 2 for profile tracks. (p2) North-South deformation component profiles for the September 2003 to May 2005 periods (blue-AA'; red- $\mathrm{BB}^{\prime}$ profiles). See Figure 2 for profiles location. Note that the maximum deformation values correlate well with the areas with a maximum change in elevation between DEMs at different epochs. 
Both datasets (see Supplementary Material for data correlation) agree in showing a significant seaward motion of the ground on the upper northeastern part of the SdF. The maximum displacements seem to be located by both techniques at an elevation of about $550 \mathrm{~m}$, just below the slope rupture bordering the terrace affected by vents opening during the 2002-2003 eruption, where the GBInSAR system also detected even larger displacements $[23,24]$. THEODOROS benchmark SDF16 clearly limits the instability towards SW, confining the sliding part on the north-easternmost side of the SdF; this sector could represent the downward prolongation of the most mobile sectors, detected just below the summit craters by the ground-based InSAR [25]. Benchmark SDF7 also confirms the stability of the central part of the SdF. Downslope, SDF5, and SDF6 reflectors reveal that the flank instability does not affect the entire side of the SdF down to the coastline but is confined to its upper part. Furthermore, both datasets concur in showing a decreasing motion in time, suggesting an evolution of the phenomena toward a progressive stabilization of the flank.

\section{Discussion}

We produced very dense ground deformation maps with the resolution of the aerial images; these images were also validated and constrained by ground truth, as, for example, is usually done on Etna $[26,27]$. Figure 3 displays the measured deformation patterns using the proposed correlation method. The smooth deformation pattern for the 2003-2004 period (upper row) may indicate the prevalence of the thermal-contraction of the lava terrace volume with respect to the slope movement (as also observed after the 2007 eruption by the authors of [18]). As cooling of the lava terrace continues, it seems that the slope movement became the dominant deformation process in the SdF (2004-2005 period), confirming what was observed by the authors of [28], and both the shape of the unstable portion and the sharp upper border of the detachment along a NE-SW line (perpendicular to the maximum slope) are well defined. During this period, a two-fracture system was developed: a main NE-SW fracture system in line with the main slope rupture of the pre-lava terrace emplacement topography (see the AA' profile in Figure 3 parallel to the maximum slope direction) and a secondary parallel NE-SW fracture in another minor buried topography slope rupture; similar ground cracks have also been detected in successive periods and imputed to shallow-seated gravitational motion of the volcanoclastic cover of the northernmost part of the SdF [25]. The profile BB' in Figure 3 also indicates the importance of the thickness in the deformation rates- the thicker the cover of lava flows, the higher the deformation rates.

\section{Conclusions}

The cumulative displacement (2003-2005) is dominated by the larger failure process deformation of the 2004-2005 period. The first period seems to be controlled by the lava thickness contraction. The results of this work image the ground motion affecting the SdF from 2003 to 2005 well, highlighting the shape and borders of the incipient slope failure and are in good agreement with InSAR data collected just upwards towards the summit crates area [25]. The direction of the motion is also in agreement with InSAR and field data, producing NE-SW ground cracks and fractures that, when deep-seated, could act as a preferential means of lateral intrusions from the summit craters, feeding lower eruptive vents in the SdF [25].

The optical correlometry results provide centimeter-to-meter displacement maps with very high spatial resolution (few meters), although mainly in the horizontal components; therefore when combined with additional techniques, i.e., THEODOROS, a wide range of topographic changes can be tracked. This combined approach successfully defines the shape and dimension of the slope-moving materials, providing important parameters, together with the kinematics of the motion, for hazard evaluations.

Multisensor combinations are a powerful approach to obtaining very dense ground deformation maps (see also [26,27,29-31]), with the spatial resolutions of a few meters. The proposed integrated approach may prove very useful for monitoring hazardous processes producing significant surface 
deformation in highly inaccessible places such as the SdF at Stromboli, where implementing ground-based systems is difficult and even dangerous (e.g., [31]). This combination of ground-based and remote sensing techniques can be useful in other deformation environments as well, such as earthquakes (see e.g., [5,7]) and landslides (see e.g., [31-33]). The validation of the correlation methodology means it can be used as the sole technique if necessary in very remote or dangerous active areas.

Supplementary Materials: The following is available online at www.mdpi.com/2072-4292/8/6/463/s1. It describes in detail the surveying network, orthoimagery processing, and correlation of measured displacement results.

Acknowledgments: This Research has been supported by the Spanish Ministry of Economy and Competitiveness research projects AYA2010-17448 and ESP2013-47780-557 C2-1-R, and the EU 7th FP MED-SUV project (contract 308665). It is a contribution to the Moncloa Campus of International Excellence. We are grateful to Giuseppe Puglisi, Massimo Cantarero and all colleagues working on the THEODOROS system. We also acknowledge Maria Marsella (Sapienza, Universita di Roma) for providing access to the orthoimagery and digital elevation models used in this study. Thanks are due to Stephen Conway for reviewing the language of the manuscript.

Author Contributions: Alessandro Bonforte led the writing of the manuscript and worked on the THEODOROS monitoring system and data. Pablo J. Gonzalez designed the experiment, processed and analyzed the aerial photogrammetric data, and collaborated with the writing of the paper. José Fernandez organized the collaboration, obtained data, and participated in the writing of the paper.

Conflicts of Interest: The authors declare no conflict of interest.

\section{References}

1. Coltelli, M.; Proietti, C.; Branca, S.; Marsella, M.; Andronico, D.; Lodato, L. Analysis of the 2001 lava flow eruption of Mt. Etna from three-dimensional mapping. J. Geophys. Res. 2007, 112, F02029. [CrossRef]

2. Marsella, M.; Baldi, P.; Coltelli, M.; Fabris, M. The morphological evolution of the Sciara del Fuoco since 1868: Reconstructing the effusive activity at Stromboli volcano. Bull. Volcanol. 2012, 74, 231-248. [CrossRef]

3. Baldi, P.; Fabris, M.; Marsella, M.; Monticelli, R. Monitoring the morphological evolution of the Sciara del Fuoco during the 2002-2003 Stromboli eruption using multi-temporal photogrammetry. ISPRS J. Photogramm. Remote Sens. 2005, 59, 199-211. [CrossRef]

4. González, P.J.; Bagnardi, M.; Hooper, A.J.; Larsen, Y.; Marinkovic, P.; Samsonov, S.V.; Wright, T.J. The 2014-2015 eruption of Fogo volcano: Geodetic modeling of Sentinel-1 TOPS interferometry. Geophys. Res. Lett. 2015, 42, 9239-9246. [CrossRef]

5. Leprince, S.; Barbot, S.; Ayoub, F.; Avouac, J.P. Authomatic and precise orthorectification, coregistration, and subpixel correlation of satellite images, Application to Ground Deformation measurements. IEEE Trans. Geosci. Remote Sens. 2007, 45, 1529-1558. [CrossRef]

6. De Michele, M.; Briole, P. Deformation between 1989 and 1997 at Piton de la Fournaise volcano retrieved from correlation of panchromatic airborne images. Geophys. J. Int. 2007, 169, 357-364. [CrossRef]

7. González, P.J.; Chini, M.; Stramondo, S.; Fernández, J. Coseismic horizontal offsets and fault trace mapping using phase correlation of IRS satellite images: The 1999 Izmit (Turkey) earthquake. IEEE Trans. Geosci. Remote Sens. 2010, 48, 2242-2250. [CrossRef]

8. Walter, T.R.; Ratdomopurbo, A.; Aisyah, N.; Brotopuspito, K.S.; Salzer, J.; Lühr, B. Dome growth and coulée spreading controlled by surface morphology, as determined by pixel offsets in photographs of the 2006 Merapi eruption. J. Volcanol. Geotherm. Res. 2013, 261, 121-129. [CrossRef]

9. Slatcher, N.; James, M.R.; Calvari, S.; Ganci, G.; Browning, J. Quantifying effusion rates at active volcanoes through integrated time-lapse laser scanning and photography. Remote Sens. 2015, 7, 14967-14987. [CrossRef]

10. Gillot, P.Y. Histoire volcanique des Iles Eoliennes: Arc insulaire or complexe orogenique anulaire? Doc. Trav. IGAL 1987, 11, 35-42.

11. Bonforte, A.; Guglielmino, F. Transpressive strain on the Lipari-Vulcano volcanic complex and dynamics of the "La Fossa" cone (Aeolian Islands, Sicily) revealed by GPS surveys on a dense network. Tectonophysics 2008, 457, 64-70. [CrossRef]

12. Angelica, C.; Bonforte, A.; Distefano, G.; Serpelloni, E.; Gresta, S. Seismic potential in Italy from integration and comparison of seismic and geodetic strain rates. Tectonophysics 2013, 608, 996-1006. [CrossRef] 
13. Linde, N.; Baron, L.; Ricci, T.; Finizola, A.; Revil, A.; Muccini, F.; Cocchi, L.; Carmisciano, C. 3-D density structure and geological evolution of Stromboli volcano (Aeolian Islands, Italy) inferred from land-based and sea-surface gravity data. J. Volcanol. Geotherm. Res. 2014, 273, 58-69. [CrossRef]

14. Tibaldi, A. Multiple sector collapses at Stromboli volcano, Italy: How they work. Bull. Volcanol. 2001, 63, 112-125. [CrossRef]

15. Puglisi, G.; Bonaccorso, A.; Mattia, M.; Aloisi, M.; Bonforte, A.; Campisi, O.; Cantarero, M.; Falzone, G.; Puglisi, B.; Rossi, M. New integrated geodetic monitoring system at Stromboli volcano (Italy). Eng. Geol. 2005, 79, 13-31. [CrossRef]

16. Bonforte, A.; Aloisi, M.; Antonello, G.; Casagli, N.; Fortuny-Guash, J.; Guerri, L.; Nunnari, G.; Puglisi, G.; Spata, A.; Tarchi, D. Movements of the Sciara Del Fuoco. In The Stromboli Volcano: An Integrated Study of the 2002-2003 Eruption; Calvari, S., Inguaggiato, S., Puglisi, G., Ripepe, M., Rosi, M., Eds.; American Geophysical Union: Washington, DC, USA, 2008; pp. 183-199.

17. Tinti, S.; Pagnoni, G.; Zaniboni, F.; Bortolucci, E. Tsunami generation in Stromboli Island and impact on the south-east Tyrrhenian coasts. Nat. Hazard Earth Syst. Sci. 2003, 3, 299-309. [CrossRef]

18. Bonaccorso, A.; Bonforte, A.; Gambino, S.; Mattia, M.; Guglielmino, F.; Puglisi, G.; Boschi, E. Insight on recent Stromboli eruption inferred from terrestrial and satellite ground deformation measurements. J. Volcanol. Geotherm. Res. 2009, 182, 172-181. [CrossRef]

19. Aloisi, M.; Bonforte, A.; Mattia, M.; Puglisi, G. Ground deformations related to the effusive eruptions of Stromboli: The 2002-2003 case. In The Stromboli Volcano: An. Integrated Study of the 2002-2003 Eruption; Calvari, S., Inguaggiato, S., Puglisi, G., Ripepe, M., Rosi, M., Eds.; American Geophysical Union: Washington, DC, USA, 2008; pp. 247-257.

20. Baldi, P.; Coltelli, M.; Fabris, M.; Marsella, M.; Tommasi, P. High precision photogrammetry for monitoring the evolution of the NW flank of Stromboli volcano during and after the 2002-2003 eruption. Bull. Volcanol. 2008, 70, 703-715. [CrossRef]

21. González, P.J. Medida y Caracterización de Deformaciones Usando Técnicas Geodésicas y de Teledetección. Aplicación en Volcanología y Sismotectónica. Ph.D. Thesis, Universidad Complutense de Madrid, Madrid, Spain, 2010.

22. González, P.J.; Baldi, P.; Bonforte, A.; Fabris, M.; Fernández, J.; Marsella, M.; Puglisi, G.; Sonnessa, A.; Spata, A. Horizontal deformation patterns of an instable lava terrace at Sciara del Fuoco, Stromboli volcano (2003-2005) by using aerial image cross-correlation. In Geophysical Research Abstracts, Proceedings of the EGU General Assembly, Vienna, Austria, 19-24 April 2009; p. 10853.

23. Antonello, G.; Casagli, N.; Farina, P.; Leva, D.; Nico, G.; Sieber, A.J.; Tarchi, D. Ground-based SAR interferometry for monitoring mass movements. Landslides 2004, 1, 21-28. [CrossRef]

24. Di Traglia, F.; Nolesini, T.; Intrieri, E.; Mugnai, F.; Leva, D.; Rosi, M.; Casagli, N. Review of ten years of volcano deformations recorded by the ground-based InSAR monitoring system at Stromboli volcano: A tool to mitigate volcano flank dynamics and intense volcanic activity. Earth-Sci. Rev. 2014, 139, 317-335. [CrossRef]

25. Di Traglia, F.; Intrieri, E.; Nolesini, T.; Bardi, F.; Del Ventisette, C.; Ferrigno, F.; Frangioni, S.; Frodella, W.; Gigli, G.; Lotti, A.; et al. The ground-based InSAR monitoring system at Stromboli volcano: Linking changes in displacement rate and intensity of persistent volcanic activity. Bull. Volcanol. 2014, 76, 786-803. [CrossRef]

26. Guglielmino, F.; Bignami, C.; Bonforte, A.; Briole, P.; Obrizzo, F.; Puglisi, G.; Stramondo, S.; Wegmuller, U. Analysis of satellite and in situ ground deformation data integrated by the SISTEM approach: The April 3, 2010 earthquake along the Pernicana fault (Mt. Etna-Italy) case study. Earth Planet. Sci. Lett. 2011, 312, 327-336. [CrossRef]

27. Bonforte, A.; Guglielmino, F.; Puglisi, G. Interaction between magma intrusion and flank dynamics at Mt. Etna in 2008, imaged by integrated dense GPS and DInSAR data. Geochem. Geophys. Geosyst. 2013, 14, 2818-2835. [CrossRef]

28. Nolesini, T.; Di Traglia, F.; Del Ventisette, C.; Moretti, S.; Casagli, N. Deformations and slope instability on Stromboli volcano: Integration of GBInSAR data and analog modeling. Geomorphology 2013, 180, 242-254. [CrossRef]

29. Muller, C.; del Potro, R.; Biggs, J.; Gottsmann, J.; Ebmeier, S.K.; Guillaume, S.; Cattin, P.H.; Van der Laat, R. Integrated velocity field from ground and satellite geodetic techniques: Application to Arenal volcano. Geophys. J. Int. 2015, 200, 861-877. [CrossRef] 
30. Bonforte, A.; Carnazzo, A.; Gambino, F.; Guglielmino, F.; Puglisi, G. A multidisciplinary study of an active fault crossing urban areas: The Trecastagni fault at Mt. Etna (Italy). J. Volcanol. Geotherm. Res. 2013, 251, 41-49. [CrossRef]

31. Pesci, A.; Teza, G.; Casula, G.; Fabris, M.; Bonforte, A. Remote Sensing and Geodetic Measurements for Volcanic Slope Monitoring: Surface Variations Measured at Northern Flank of La Fossa Cone (Vulcano Island, Italy). Remote Sens. 2013, 5, 2238-2256. [CrossRef]

32. Hungr, O.; Leroueil, S.; Picarelli, L. The Varnes classification of landslide types, an update. Landslides 2014, 11, 167-194. [CrossRef]

33. Casson, B.; Delacourt, C.; Baratoux, D.; Allemand, P. Seventeen years of the "La Clapière" landslide evolution analyzed from ortho-rectified aerial photographs. Eng. Geol. 2003, 68, 123-139. [CrossRef]

(C) 2016 by the authors; licensee MDPI, Basel, Switzerland. This article is an open access article distributed under the terms and conditions of the Creative Commons Attribution (CC-BY) license (http:/ / creativecommons.org/licenses/by/4.0/). 